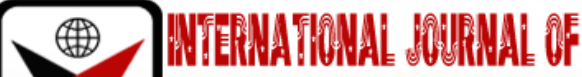 \\ בmRक
}

ISSN 2278 - 0211 (Online)

\section{Contractors Pre-Qualification Guideline Used in Contractor Selection for Public Building Project in Southeast Nigeria: A Case Study of Imo State, Nigeria}

Ezeh Christian Chinedu
Lecturer, Department of Building, Imo State University, Nigeria
Okolie Kelvin C.
Professor, Department of Building, NnamdiAzikiwe University Awka, Nigeria
Dr. Nkeleme Emmanuel Ifeanyichukwu
Lecturer, Department of Building,Federal University of Technology Owerri Imo State, Nigeria
Okereke Godson
Lecturer, Department of Building, Federal University of Technology Owerri, Nigeria
Ayuba Mikhail Suleiman
Postgraduate Student, Department of Building, Ahmadu Bello University, Nigeria

\begin{abstract}
:
The incessant poor project delivery of contractors in the execution of public buildings is a reoccurring decimal in various areas of southeast Nigeria and the salient question people keep asking is if the qualified contractor is engaged and by extension the basis of assessment of contractors before engagement? It is in response to this curiosity that this paper set out to evaluate the prequalification guideline/criteria used in engaging contractors in Southeast Nigeria, using Imo state as a case study. It was pursued, using literature review and field survey entailing the use of a wellstructured questionnaire. A total of three hundred and eighty-four (384) questionnaires were distributed with three hundred and fifty (350) returned adequately filled giving a response rate of 91.0\% The responses were analyzed using the SPSS software version 25. The result revealed among others; Some of the contracts are not awarded regarding any specific selection guideline but basically on executive awards; in few cases where contractors are selected based on an in-house performance evaluation, the most demanded document arranged in the order of frequency of demand are: financial capacity/Bank support Document'; 'Building Construction license'. Finally, the study recommendsa thorough examination of contractors at the pre-selection phases before engaging any contractor. This is to ensure that competent and qualified contractors only engage and adequate project delivery within the study area.
\end{abstract}

Keywords: Pre-qualification guidelines, contractors, public building project

\section{Introduction}

The Construction Industry contributes significantly to the Gross Domestic Products (GDP) of a nation and prides itself as the industry that produces one of the three most basic needs of man i.e. shelter, for the protection of man and property from the harsh effects of weather.

One key feature of the Construction Industry is the use of a contract system involving the employment of Contractors in projects production processes, especially in the public sector. This is due to the peculiarity of the industry's production processes and products. The contract system is particularly very necessary in the execution of building projects in the Construction Industry due to the size and complexity of most building projects. Such projects would otherwise be extremely difficult to be directly coordinated and produced to a successful, logical conclusion by project owners who, in most cases, may not possess the requisite expertise. Constraints such as lack of technical and managerial competence, time, staff, and cash flow requirements in project execution also make the contract system and use of Contractors indispensable in the construction industry.

Mbachu (2012) identified the Contractor as a key player that maintains vital links with other role players in the Building Construction Supply Chain. The Contractor provides all the necessary materials, labor, plant, and equipment and executes the Building Project to the satisfaction of the employer-based on pre-stated construction directives i.e. design and specifications of the employer.

The National Building Code (NBC, 2006) defines the Contractor as 'a person or firm who contracts with an owner of a project or his authorized agent to undertake the execution of a project.' He is a businessman whose primary objective in the contract business is to maximize profit. Contractors are critical role players in the construction industry and their performance greatly impacts the performance and productivity of the industry. 
Despite the tremendous contributions of contractors and the Construction Industry to the growth and development of nations, their success stories are diminished by their global and local gloomy pictures. In the United States of America for instance, construction productivity remains one of the least understood factors in the American economy and the bureau of labor statistics maintains productivity indices for all significant sectors of the economy except the construction sector due to lack of suitable data (CIMA, 2010).

In Nigeria, the performance of Contractors and the Construction Industry is generally perceived as very poor. According to Mbamali (2009), construction contracting in Nigeria witnessed an upsurge during the oil boom of the 1970s and up to the end of the Second Republic in 1983. As a result of the poor performance of Contractors in the execution of projects in the Nigerian Construction Industry, the Construction Industry is the most misunderstood sector in the Nigerian economy and is very lowly rated in the construction performance index (CPI) of African Countries. According to Usman and Alaezi (2016), the industry accounts for only about 5\% of GDP in Nigerians as compared with South African (19\%), Ghana (8\%), and Mexico (17.7\%). Obiegbu (1992), noted that the construction sector in Nigeria holds the record for lowest profits of any manufacturing industry in the country and usually top the list in the bankruptcy league. One of the ways to enhance contractor performance and improve productivity in the execution of public building projects is through evaluation of contractor performance using track record performance indices/indicators. Such evaluation will help to enrich building design and specification, guide and attract contractors towards better performance and productivity, and give clients better value for their money. Such evaluation will also eliminate problems of poor building delivery, time and cost overrun, and building collapse.

Also, in Nigeria, and the study area in particular where the traditional contract system is mostly in use, in the public sector, the performance of the contractor is generally perceived as very poor Despite the tremendous contribution of Contractors and the construction industry to contractor economic growth and development nations, their productivity remains one of the least understood in the Nigerian economy. The question is 'are the qualified contractors engaged? What are the prequalification criteria used in the selection of contractors for the execution of Public building projects in SouthEast Nigeria and Imo State in particular?

Unfortunately, there is a lack of relevant data for such evaluation of contractors in the Nigerian construction industry and the study area as a result, contractors are not attracted or encouraged towards efficient and effective performance which guarantees the enhanced realization of set project objectives in building construction. The result is that contractor performance in a public building, especially in the Imo State of Nigeria, has continued to dwindle. Consequently, the problems of poor quality building delivery, high early building maintenance, high major site accidents, building collapse, project time, and cost overruns have become the hallmark of the execution of building projects by contractors in the public sector of the study area. It is on the premisesof the existing challenge that this research sought to identify the contractor's pre-qualification criteria used in engaging the contractors to know if the multiple failures in a public building project area product of wrong selection or engagement of unqualified contractors.

\section{Literature Review}

\subsection{Contractor}

A 'contractor' is any person who is engaged, other than as an employee, by another to do work for gain or reward. They may be a self-employed person, corporate entity, or a person engaged on some other basis than as an employee. In other words, A contractor is a person or a company that seeks to do business by obtaining contracts and carrying them out. Being a contractor is similar to being a business owner - you negotiate your deals, work for yourself, have your clientele, and are rewarded on your own merits. A construction contractor offers a particular suite of skills that he can perform for clients on a contractual basis. As a contractor, you will likely be paid more for work than you would be as a worker because you have put in the effort of finding the customer yourself. Therefore, any profits from contract work belong to the contractor.

\subsection{Who is a Subcontractor?}

A subcontractor is a type of contractor. Subcontractors also work on a contractual basis, and they also offer a particular set of skills that they perform for customers. The key point about subcontractors is that they form agreements with the contractor, not with the customer. Subcontractors often specialize in one specific area of construction and try to network with contractors who negotiate for larger jobs that include this area of specialty. In this way, a successful subcontractor will always have work, thanks to their network of contractors.

\subsection{Criteria for the Selection of Construction Project Contractor}

Contractor evaluation is often performed by industry professionals using their accumulated experience and judgment. There are variations in the amount of effort expended in the process, often without an understanding of how such variations influence the project outcome. An important step in evaluation is to examine the contractor's system for handling project information regarding work tasks. The contractor's approach to safety and what actions it takes to achieve desired results should be closely scrutinized. (Atkinson, 1999). Many factors should be considered during the contractors' qualification screening. The following list includes most of the key components that should be examined when conducting a contractor qualification.

- Financial standing, such as financial stability, turnover, profit, obligations, amounts due, and owned financial funds.

- Technical and professional ability, such as experience, plant and equipment, and personnel. 
- Management capability, such as past performance and quality, quality control policy, quality management system, project management system, the experience of technical personnel, and management knowledge.

- Quality, safety, senior management, including experience, tenure with the firm, and division of responsibilities.

- Current projects/backlog, including number, size, and location of projects, percent of capacity being utilized, and status and expected completion, past failures in completed projects, number of years in construction, past client relationships, and cooperation with Consultant/Contactors (Salaheldin., 2009).

One way to collecting the data necessary to perform contractor evaluations is to conduct questionnaires. But in this way, contractors will be tempted to answer in a way that puts them in the best light. For instance, one commonly used questionnaire asks contractors if safety is a priority in their business. (Gatere et al., 2013). The key to a successful methodology is to develop an objective form, from which a database can be built that allows for fair comparisons of contractors. The form should be easy to use. Anyone on the bid evaluation team should be able to conduct the assessment and compare the results (Lin and Lee 2011). Furthermore, owners must carefully analyze the data submitted by contractors. It is not prudent to ask the contractor to provide answers about the viability and completeness of its program and then simply rely on those answers when concluding the effectiveness of its efforts. (Lin\&Lee, 2000). Objective information needs to be obtained and, more importantly, mechanisms for verifying the accuracy of the data need to be developed before any conclusions can be drawn (Beatham\&Anumba 2004).

\subsection{Analysis of the Contractor in the Construction Project}

Project construction must be managed effectively. The demands from clients, competition, and regulatory agencies have been growing rapidly (Ahadzie, 2007). These challenges present a paradox: few of these demands directly contribute to the physical construction of the project. However, a failure to properly manage them can lead to problems for the entire project and construction team. The selection of a proper construction contractor increases the chances of successful completion of a construction project. It can also fulfill the client's goals, and keep the schedule of the cost, time, and quality. So it is extremely critical to select an appropriate contractor in the process of construction management (Takim and Akintoye, 2002)

The selection of construction contractors is very often conducted during tendering. Tendering indeed gives a client a choice in awarding the contract to a company that proposes the lowest price and short construction cycles, but usually, they do not allow to precisely evaluating a tenderer. At the same time, there are more and more procedures in which the decisive criterion of choosing a tender is the price. In recent years, most clients made use of such a method. (Willis \& Willis 1996). On the other hand, the research results show that the cheapest tenderers often have problems with completing the project. Accepting the lowest price is the basic cause of the project completion problems because very often lowering the price means lowering the quality. It is true in some cases. The above conditions make that it is especially important to properly evaluate the contactor's capabilities. We analyzed in this paper the frameworks applied in the selection of construction project contractors and summarized the criteria for selecting a suitable contractor. (Kobia, and Mohammed, 2006). It is complicated to select a suitable contractor. Bid evaluation is one of the major challenges that face owners and consultants in the public and private sectors. Nevertheless, there are objective means to gauge the ability of a contractor to properly manage the business aspects of the construction project (Gatere et al., 2013). Some models and frameworks have been created to evaluate contractors' bids and select the most appropriate one. The evaluation can be done beforehand with a prequalification method to ensure the quality of contractors. Facing the owner's scrutiny regarding its competency to handle the business aspects of the operation during prequalification allows the contractor to focus on the specifics of the construction project once it has passed through prequalification and been short-listed. This also allows the owner's bid evaluation team to focus only on the specific elements of the project, without being distracted by the other business considerations. (Shaban,2008). In the simplest meaning prequalification is a before tendering procedure that allows choosing the most appropriate candidates from amongst those declaring willingness to participate in the tendering. The aim of prequalification is often not only contractor competence evaluation but also a limitation of potential bidders. In such a case it is necessary not only to judge whether the contractor fulfills the basic criteria but also to what degree they are fulfilled. Not all criteria are equally important for the client. The basic issue is assigning the right weights to the criteria. (Kobia, and Mohammed, 2006).

However, there is also a defect in the prequalification method. Time will necessarily pass between when the contractor is qualified and when it submits its bid. Things within the firm could change. This problem can be corrected with an update of the qualification data during the bid. The problem with performing contractor assessments during bidding is that it adds steps to the bid evaluation process. It requires evaluating both the contractor's business competency and its qualifications as a builder in the same process. In practice, prequalification can be a form of 'registering' the contractors capable of completing given tasks. (Dooren., 2006). Contractors are usually grouped depending on some chosen factors, like possessing specialist equipment to perform a given type of works. The following groups of criteria have been suggested:

- Responsiveness, promptness, realism, completeness.

- Meeting deadlines, correctness and valid information, totality in providing information.

- Responsibility, obeying the law, and complying with local government regulations, standards, and bylaws, quality system, safety system.

- Competence, recourse (financial, machinery, plant and equipment, human resources), experience, constraints. (Ugwu\&Haupt 2007). 


\section{Methodology}

\subsection{Research Design}

This research was pursued through fieldwork. The Fieldwork entails the use of an interview of the head of the department of the agencies directly or indirectly involved in the award of contract and the various contractors among others. The research also adopted the use of a structured questionnaire administered to contractors, Consultants, Contractor/consultant employees, and the statutory inspectors/supervisors to establish their opinion onthe contractor's pre-qualification criteria or guidelines in the execution of public building projects within the study area

\subsection{Method of Data Collection}

The primary data for this survey was collected using a structured questionnaire and an interview, while secondary data was obtained from books, journals, magazines, conference/seminar papers will be utilized. The questionnaires were used for data collection and were administered to various professionals in the construction industry broadly categorized into three as the supervisor, contractor, and consultant respectively.

\subsection{Population and Sample of the Study}

The population for the study are the stakeholders and also construction professionals majorly responsible for public building projects delivery in Nigeria. They include professionals involved in the Nigerian Construction Industry irrespective of the fact that they can belong to any of the following Categories: clients, consultants, and contractors. This categorization was to ensure that all information obtained from the structured questionnaires guarantee a reasonable level of validity to achieve the aim of this research work

\subsection{Sample, Sample Size, and Techniques}

The term 'sample' means a specimen or part of a whole (population) which is drawn to show what the rest is like (Nauom, 2007). The techniques/Strategies for determining sample size according to Glenn (2013) are

- Using the census for a small population

- Using a sample size of a similar study

- Using published table

- Using a formula to calculate the sample size (e.g. Yaro Yamani Formular or cochraoas formula)

However, Cochran's sample size calculation procedure was employed to determine the appropriate sample size in this study. To do this, Cochran's return sample size formula is first determined using the formula presented in equation 1 (Cochran, 1977)

$$
n_{0}=\frac{\left(t^{2}\right) \times(p)(q)}{\left(d^{2}\right)}
$$

Where:

$>\quad \mathrm{t}=$ value of selected alpha level usually 0.025 in each tail of a normal distribution obtained as 1.96 (the alpha level of 0.05 indicating that the risk the researcher is willing to take that the true margin of error exceeds the acceptable margin of error is $5 \%$ ).

$>\quad(\mathrm{p})(\mathrm{q})=$ this is the estimate of variance given as $(0.5)(0.5)=0.25$

$>\quad \mathrm{d}=$ acceptable margin of error for proportion being estimated given as 0.05 (this is the error level the researcher is willing to expect).

Thus, after calculating the Cochran's return sample size no (see Equation 1), we will employ Cochran's correction formula to obtain the appropriate or final sample size, and the formula is given in equation (1) as:

$$
n_{0}=\frac{\left(1.96^{2}\right) \times(0.5)(0.5)}{\left(0.05^{2}\right)}
$$$$
=384
$$
equation 1

Applying equation, gave a sample of 384 as presented equation 1

Thus, the sample size of the respondents for this study is 384 .

\subsection{Questionnaire Administration}

Data werecollected with the aid of structured questionnaires which the respondents' were drawn from the twenty-seven local government area of Imo state. These locations were chosen because of the vast public building construction project going on simultaneously in the state initiated the state government. The targeted respondents of the questionnaire were the Consultants, contractors, and supervisors of such public building construction because they are in the right position to have adequate information regarding the pre-qualification criteria/guideline used to secure the contracts. A total of 384 self-administered questionnaires were distributed to respondents in the target population, 350 were returned and found appropriate for the analysis. 


\section{Method of Analysis and Data Presentation}

In the analysis of data to be obtained in the study, both descriptive and referential data analysis will be adopted. Bar Charts, Pie Charts, Tables, means, percentages, and charts will be used to express the statistical results. Charts like bar and Pie charts will also be used to present results. Suitable statistical tools were adopted in the analysis. The Statistical Package for Social Sciences (SPSS) software was used to analyze the data using descriptive statistics Relative importance index will also be used in the study to assess the results.

Relative importance index. (RII) $=\frac{\sum f x}{\sum f} x \frac{1}{k}$

Where,

$\Sigma \mathrm{fx}=$ is the total weight given to each attribute by the respondents

$\Sigma \mathrm{f}=$ is the total number of respondents in the sample

$\mathrm{K}=$ is the highest weight on the Likert scale.

The ranking of the items under consideration will base on their RII values. The item with the highest RII value will be ranked first (1) the next (2) and so on. The interpretation of the RII values is achieved when,

$\mathrm{RII}<0.60$, the item is assessed to have a 1ow rating

$0.60 \geq \mathrm{RII}<0.80$, item assessed to have high rating

$\mathrm{RII} \geq 0.80$ items assessed to have a very high rating

Also using mean for the interpretation their extent of prevalence as either low, moderate, or high based on the following boundaries (level of measurement) developed by Ruikaret al. (2006):

- a mean rating with value $0.00<x<2.50$ is considered 'Low'

- a mean rating with value $2.50<\mathrm{x}<3.50$ is considered 'Moderate'; and

- a mean rating with value $3.50<\mathrm{x}<5.00$ is considered 'High'.

\section{Data presentation and Discussion}

This section presents the result of the data analysis of the respondents' opinion and it is divided into various subsections for simplicity

\subsection{Respondents Profile}

Information regarding the categories of respondents and other features of the respondents are as presented in Table 1. From the Table, it can be deduced that $24.6 \%$ of the respondents were the contractors' employees; $23.8 \%$ of the respondents were contractors as well as the same percentage for consultants, however, $21.1 \%$ of the respondents were consultant employees with only $6.7 \%$ of the respondent that were Statutory inspector/supervisors.

With regards to the working experience of the respondent in the construction industry, a larger percentage of the respondent (43.5\%) were within the bracket of 6-10years. This was followed closely by $19.7 \%$ of the respondents with the age bracket of 11-15yrs, details of the working experience distribution are given in the Table. The Table further presents the highest qualification distribution of the respondents as MSc (28.3\%), BSc (23.3\%), HND (21.5\%), and Diploma (5.8\%). In addition to the profile of the respondents, the Table also reveals the professional background of the respondents. From the Table, $24.9 \%$ of the respondents were Builders; $18.6 \%$ architects; $15.4 \%$ town Planners; $14.3 \%$ Quantity Surveyors, and $10.3 \%$ as estate managers. The respondents also indicated the duration of their involvement in the execution of public building projects in Imo State; and to that effect, 28.9\%(6-10yrs), 25.3\%(0-5yrs), 24.9\%(11yrs-15yrs), and 20.9\% (16yrs and above). Other details regarding the respondent's profile are as indicated in the Table.

\begin{tabular}{|c|c|c|c|c|}
\hline $\mathbf{S} / \mathbf{N}$ & Variable & Option & $\begin{array}{l}\text { Frequency } \\
\text { (No) }\end{array}$ & $\begin{array}{c}\text { Percentage } \\
(\%)\end{array}$ \\
\hline \multirow[t]{6}{*}{1} & \multirow[t]{6}{*}{ category of respondents } & Contractor & 83 & 23.8 \\
\hline & & Contractors employee & 86 & 24.6 \\
\hline & & Consultant & 83 & 23.8 \\
\hline & & Consultant employee & 74 & 21.1 \\
\hline & & $\begin{array}{l}\text { e) Statutory/government } \\
\text { inspector/supervisors }\end{array}$ & 24 & 6.7 \\
\hline & & Total & 350 & 100 \\
\hline \multirow[t]{6}{*}{2} & \multirow{6}{*}{$\begin{array}{l}\text { Duration of work in the } \\
\text { construction industry }\end{array}$} & $0-5 y r$ & 61 & 17.5 \\
\hline & & 6-10yrs & 152 & 43.5 \\
\hline & & 11-15yrs & 69 & 19.7 \\
\hline & & 16-20yrs & 42 & 12.1 \\
\hline & & 20yrs and above & 26 & 7.2 \\
\hline & & Total & 350 & 100 \\
\hline
\end{tabular}




\begin{tabular}{|c|c|c|c|c|}
\hline $\mathbf{S} / \mathbf{N}$ & Variable & Option & $\begin{array}{l}\text { Frequency } \\
\text { (No) }\end{array}$ & $\begin{array}{c}\text { Percentage } \\
(\%)\end{array}$ \\
\hline \multirow[t]{7}{*}{3} & \multirow{7}{*}{$\begin{array}{l}\text { highest academic } \\
\text { qualification }\end{array}$} & a) Diploma & 20 & 5.8 \\
\hline & & b) HND & 75 & 21.5 \\
\hline & & c) Bachelor's Degree & 82 & 23.3 \\
\hline & & d) Post Graduate Diploma & 74 & 21.1 \\
\hline & & e) Master's Degree & 99 & 28.3 \\
\hline & & Doctorate Degree & - & - \\
\hline & & Total & 350 & 100 \\
\hline \multirow[t]{8}{*}{4} & \multirow[t]{8}{*}{ professional background } & Architecture & 65 & 18.6 \\
\hline & & Building & 87 & 24.9 \\
\hline & & Quantity surveying & 50 & 14.3 \\
\hline & & Town Planning & 54 & 15.4 \\
\hline & & Estate Management & 36 & 10.3 \\
\hline & & Engineering & 30 & 8.6 \\
\hline & & Land Surveying & 28 & 7.9 \\
\hline & & Total & 350 & 100 \\
\hline \multirow[t]{6}{*}{5} & \multirow{6}{*}{$\begin{array}{l}\text { designation in your } \\
\text { organization }\end{array}$} & Managing Director/CEO & 12 & 3.4 \\
\hline & & $\begin{array}{l}\text { b) Project } \\
\text { Consultant/Supervisor }\end{array}$ & 56 & 16.0 \\
\hline & & Manager & 97 & 27.7 \\
\hline & & Site manager/engineer & 99 & 28.3 \\
\hline & & Others & 86 & 24.6 \\
\hline & & Total & 350 & 100 \\
\hline \multirow[t]{5}{*}{6} & \multirow{5}{*}{$\begin{array}{l}\text { Duration of involvement in } \\
\text { execution of public building } \\
\text { in Imo State? }\end{array}$} & $0-5 y r s$ & 89 & 25.3 \\
\hline & & $6-10 y r s$ & 101 & 28.9 \\
\hline & & $11 \mathrm{yrs}-15 \mathrm{yrs}$ & 87 & 24.9 \\
\hline & & 16yrs and above & 73 & 20.9 \\
\hline & & Total & 350 & 100 \\
\hline \multirow[t]{7}{*}{7} & \multirow{3}{*}{$\begin{array}{l}\text { Condition of the Public } \\
\text { Building Project used fr the } \\
\text { study }\end{array}$} & a) & 56 & 16.0 \\
\hline & & b) & 42 & 12.0 \\
\hline & & c) & 55 & 15.7 \\
\hline & \multirow{4}{*}{$\begin{array}{c}\text { 1= completed, } 2=\text { not } \\
\text { completed, } 3=\text { on-going } \\
\text { project }\end{array}$} & $1 \& 2$ & 34 & 9.7 \\
\hline & & $2 \& 3$ & 67 & 19.1 \\
\hline & & $1,2 \& 3$ & 96 & 27.5 \\
\hline & & Total & 350 & 100 \\
\hline
\end{tabular}

Table 1: Respondents Profile

Source: Field Survey, (2019)

\subsection{Contractor Selection Guideline and Pre-Selection Performance Factors}

The result of the respondents' opinions on the contractor selection guideline and the decision criteria used in the selection of contractors are presented in Table 2. From the Table, it can be deduced that most of the contractors are selected based on an 'In house performance evaluation guideline (52.5\%). However, 23.8\% of the respondents opined that the selection criteria is the use of external agencies in the evaluation of contractors while $23.7 \%$ of the respondents claim that there is no formal evaluation process in the selection of contractors.

Also, with regards to the decision criteria in the selection of contractors a large percentage of the respondents claim that it's done based on rating with weighing of contractors ability. Details of the percentage of respondents with a contrary opinion are as presented in the Table 


\begin{tabular}{|c|c|c|c|c|}
\hline $\mathbf{S} / \mathbf{N}$ & Variable & Option & $\begin{array}{l}\text { Frequency } \\
\text { (No) }\end{array}$ & $\begin{array}{c}\text { Percentage } \\
(\%)\end{array}$ \\
\hline \multirow[t]{5}{*}{1} & \multirow[t]{5}{*}{$\begin{array}{l}\text { Contractor Selection } \\
\text { Guideline used }\end{array}$} & $\begin{array}{l}\text { a) No formal evaluation } \\
\text { process exists }\end{array}$ & 83 & 23.7 \\
\hline & & $\begin{array}{l}\text { b) In-house performance } \\
\text { evaluation guidelines }\end{array}$ & 183 & 52.5 \\
\hline & & $\begin{array}{l}\text { c) Use external agency in } \\
\text { the evaluation }\end{array}$ & 84 & 23.8 \\
\hline & & Don't know & - & - \\
\hline & & Total & 350 & 100 \\
\hline \multirow[t]{5}{*}{2} & \multirow[t]{5}{*}{$\begin{array}{l}\text { How do you evaluate the } \\
\text { decision criteria }\end{array}$} & $\begin{array}{lll}\text { a) Rating with no } \\
\text { weighting }\end{array}$ & 61 & 17.5 \\
\hline & & Rating with weighting & 151 & 43.5 \\
\hline & & $\begin{array}{l}\text { c) Professional } \\
\text { judgment/Consultants advice }\end{array}$ & 69 & 19.7 \\
\hline & & Executive Decision & 69 & 19.3 \\
\hline & & Total & 350 & 100 \\
\hline
\end{tabular}

Table 2: Contract Selection Guideline

Source: Field Survey, (2019)

\subsection{Documents Demanded Before the Award of Contracts}

Based on the experience of respondents, the common document demanded before the award of contractor as accessed and the result of the analysis is as presented in Table 4.4. From the Table, it can be seen that the most requested document is the financial capacity/Bank support Document (RII= 0.61) as it was ranked first. This was closely followed by other documents like 'Building Construction license' (RII=0.52); 'The Construction Organizational Structure' (RII=0.48) and 'The completed questionnaire issued by the client's body (RII=0.47) which were ranked second, third and fourth respectively. Also from the general mean distribution of all the documents identified, it can be observed that the mean rating is closer to 2.0, an indication that most of the documents were occasionally demanded before the award of contracts. Details of the ranking of the demand of another document from contractors before the award of contracts are presented in the Table.

\begin{tabular}{|c|c|c|c|c|c|c|c|c|c|c|c|}
\hline \multirow[t]{2}{*}{ S/No } & \multirow{2}{*}{$\begin{array}{l}\text { Documents Demanded } \\
\text { Before the Award of } \\
\text { Contracts }\end{array}$} & \multicolumn{10}{|c|}{ Weighting/Response Frequency } \\
\hline & & 1 & 2 & 3 & 4 & 5 & $\left(\sum f\right)$ & $\sum \mathbf{f x}$ & $\begin{array}{l}\text { ME } \\
\text { AN }\end{array}$ & RII & $\begin{array}{c}\text { RAN } \\
\text { K }\end{array}$ \\
\hline 1 & $\begin{array}{l}\text { The completed questionnaire } \\
\text { issued by the clients body }\end{array}$ & 96 & 119 & 75 & 33 & 27 & 350 & 826 & 2.36 & 0.47 & $4^{\text {th }}$ \\
\hline 2 & The completed questionnaire & 127 & 88 & 80 & 30 & 25 & 350 & 788 & 2.25 & 0.45 & $5^{\mathrm{TH}}$ \\
\hline 3 & Safety policy & 165 & 58 & 123 & 4 & - & 350 & 667 & 1.91 & 0.38 & $9^{\mathrm{TH}}$ \\
\hline 4 & $\begin{array}{l}\text { Outline Construction } \\
\text { programme/ time policy }\end{array}$ & 156 & 68 & 83 & 43 & - & 350 & 707 & 2.01 & 0.40 & $8^{\mathrm{TH}}$ \\
\hline 5 & $\begin{array}{l}\text { Financial capacity/Bank } \\
\text { Support }\end{array}$ & 51 & 74 & 64 & 127 & 34 & 350 & 1066 & 3.04 & 0.61 & $1^{\text {ST }}$ \\
\hline 6 & $\begin{array}{c}\text { CVs of the key Professional } \\
\text { staff }\end{array}$ & 210 & 71 & 50 & 19 & - & 350 & 578 & 1.65 & 0.33 & $12^{\mathrm{TH}}$ \\
\hline 7 & Construction Quality policy & 176 & 89 & 36 & 49 & - & 350 & 656 & 1.88 & 0.38 & $9^{\mathrm{TH}}$ \\
\hline 8 & Tax Clearance Certificates & 152 & 105 & 93 & - & - & 350 & 641 & 1.83 & 0.37 & $11^{\mathrm{TH}}$ \\
\hline 9 & $\begin{array}{l}\text { Registration certificates with } \\
\text { Corporate Affairs Commission }\end{array}$ & 122 & 96 & 68 & 64 & - & 350 & 774 & 2.21 & 0.44 & $6^{\mathrm{TH}}$ \\
\hline 10 & Building Construction license & 80 & 88 & 68 & 114 & - & 350 & 917 & 2.62 & 0.52 & $2^{\mathrm{ND}}$ \\
\hline 11 & $\begin{array}{l}\text { Construction liability } \\
\text { insurance }\end{array}$ & 179 & 116 & 49 & 6 & - & 350 & 582 & 1.66 & 0.33 & $12^{\mathrm{TH}}$ \\
\hline 12 & $\begin{array}{l}\text { List of key construction } \\
\text { equipment owned/ to be } \\
\text { leased }\end{array}$ & 140 & 88 & 69 & 53 & - & 350 & 736 & 2.10 & 0.42 & $\begin{array}{l}\mathrm{TH} \\
\end{array}$ \\
\hline 13 & $\begin{array}{c}\text { The Construction } \\
\text { Organizational Structure }\end{array}$ & 123 & 67 & 58 & 102 & - & 350 & 843 & 2.41 & 0.48 & $3^{\text {rd }}$ \\
\hline
\end{tabular}

Table 3: Ranking of the Frequency of Demand of Documents before the Award of Contracts Source: Field Survey, (2019)

Where: 1-Not Demanded 2- Occasionally Demanded 3-Undeceive４-Often Demanded 5-Always Demanded 


\subsection{Respondents' Opinion on the Importance of Pre-Selection Contractors' Performance}

This section presents the respondent ranking of the various factors constituting the basis for the assessment of contractors for the award of public building contracts. This basis ranges from: 'Technical/professional Capacity'; 'Financial Capability; 'Health and Safety; 'Reputations'; 'Management Ability, and 'Organization Culture. The result of the respondents ranking of the various factors is presented in Table 4

\subsubsection{Ranking of the Pre-Selection Contractor Performance on Technical/Professional Capacity}

From the Table, the respondents ranked 'Engagement of technical/professional staff with relevant qualification and exposure' $(\mathrm{RII}=0.85)$ as the most important pre-selection performance factors under technical/professional capacity. This was closely followed by 'Plant and equipment: availability, conditions, and suitability of the equipment (RII=0.79); 'Quality management policy' (RII=0.77) and 'Specialized knowledge of the specified project' (RII=0.73); which were ranked second third and fourth respectively in the order of importance. Details of the ranking of other technical/professional capacities are as presented in Table 4

\subsubsection{Ranking of the Pre-Selection Contractor Performance on Financial Capability}

Also from Table 4, it presents the respondents' ranking of the financial capability in the following order of importance. 'Financial standing and stability' (RII=0.84); 'Banking Support/ Guarantee' (RII=0.83) and 'Working capital' (RII=0.73) were ranked first, second and third in their order of importance. Details of the ranking of other financial capability pre-selection contractor performance are presented in the Table.

\subsubsection{Ranking of the Pre-Selection Contractor Performance on Health and Safety}

The respondent ranked 'Site safety certification from required professional body' (RII=0.71) as the most important health and safety pre-selection contractor performance criteria. Other health and safety criteria ranked in the order of its importance are: 'Management safety policy' (RII=0.68); and 'Safety management plan from a registered builder' (RII=0.67), ranked second and third respectively. Details of the ranking of other health and safety criteria are as presented in the Table

\subsubsection{Ranking of the Pre-Selection Contractor Performance on Reputations}

From Table4.it can be seen that the respondents ranked the contractor's capability to resolve issues on Frequency of claims and contractual dispute in the previous contracts (RII=0.78) as the most important criteria on the contractor preselection performance capability. This was closely followed by 'Past client relationship/certificates of friendly project completion' (RII=0.76) and 'Reputation of the subcontractors to be used for the project' (RII=0.74) ranked second and third respectively. Details of the ranking of other criteria are as presented in the Table.

\subsubsection{Ranking of the Pre-Selection Contractor Performance on Management Ability}

With regards to the criteria for the Management ability as the pre-selection contractor performance, the respondent ranked 'Number of own workers available for the project' (RII=0.77) as the most important management ability. Other criteria considered very important by the respondents are: 'Qualification and experience level of project manager/building construction manager' (RII= 0.74), and 'Past management performance' (RII= 0.68) ranked second and third respectively. Details of the ranking other Management ability criteria are as presented in the Table

\subsubsection{Ranking of the Pre-Selection Contractor Performance on Organization Culture}

Table4 also presented the respondent ranking of the level of importance of the contractors' organization culture criteria. From the Table, it can be deduced that the respondents ranked 'Familiarity with regulating authority (RII=0.83) as the most important pre-selection contractor performance criteria. This was closely followed by: 'Contractors size and complexity ( $\mathrm{RII}=0.81$ ) and 'Familiarity with local working culture' $(\mathrm{RII}=0.76)$ which ranked second and third in the order of importance. Details of the ranking of other organization cultural criteria are as presented in the Table. 


\begin{tabular}{|c|c|c|c|c|c|c|c|c|c|c|c|}
\hline & & 1 & 2 & 3 & 4 & 5 & $(\Sigma f)$ & $\Sigma \mathbf{f x}$ & MEAN & RII & RANK \\
\hline $\mathbf{A}$ & $\begin{array}{c}\text { Technical/Professional } \\
\text { Capacity }\end{array}$ & & & & & & & & & & \\
\hline 1 & $\begin{array}{l}\text { Previous experience on } \\
\text { similar types and sizes of } \\
\text { projects completed. }\end{array}$ & - & 29 & 148 & 138 & 35 & 350 & 1229 & 3.51 & 0.70 & $5^{\mathrm{TH}}$ \\
\hline 2 & $\begin{array}{c}\text { Engagement of } \\
\text { technical/professional staff } \\
\text { with relevant qualification } \\
\text { and exposure }\end{array}$ & - & 4 & 16 & 225 & 105 & 350 & 1481 & 4.23 & 0.85 & $1^{\mathrm{ST}}$ \\
\hline 3 & $\begin{array}{c}\text { Plant and equipment: } \\
\text { availability, conditions, and } \\
\text { suitability of the equipment }\end{array}$ & - & 49 & 61 & 97 & 143 & 350 & 1384 & 3.95 & 0.79 & $2^{\mathrm{ND}}$ \\
\hline 4 & Quality management policy & 7 & 72 & 50 & 62 & 159 & 350 & 1344 & 3.84 & 0.77 & $3^{\mathrm{RD}}$ \\
\hline 5 & $\begin{array}{l}\text { Specialized knowledge of } \\
\text { the specified project }\end{array}$ & 05 & 64 & 89 & 79 & 113 & 350 & 1281 & 3.66 & 0.73 & $4^{\mathrm{TH}}$ \\
\hline B & Financial Capability & & & & & & & & & & \\
\hline 1 & $\begin{array}{c}\text { Financial standing and } \\
\text { stability }\end{array}$ & - & 25 & 82 & 45 & 198 & 350 & 1466 & 4.19 & 0.84 & $1^{\text {ST }}$ \\
\hline 2 & $\begin{array}{l}\text { Project fund disbursement } \\
\text { plan }\end{array}$ & 48 & 85 & 88 & 60 & 69 & 350 & 1067 & 3.04 & 0.61 & $6^{\mathrm{TH}}$ \\
\hline 3 & $\begin{array}{l}\text { Banking Support/ } \\
\text { Guarantee }\end{array}$ & - & 28 & 87 & 34 & 201 & 350 & 1458 & 4.17 & 0.83 & $2^{\mathrm{ND}}$ \\
\hline 4 & Financial status & 60 & 67 & 22 & 67 & 134 & 350 & 1198 & 3.42 & 0.68 & $4^{\mathrm{TH}}$ \\
\hline 5 & Working capital & 17 & 36 & 56 & 187 & 54 & 350 & 1275 & 3.64 & 0.73 & $3^{\text {RD }}$ \\
\hline 6 & Current and fixed assets & 89 & 93 & 28 & 13 & 127 & 350 & 1046 & 2.99 & 0.60 & $7^{\mathrm{TH}}$ \\
\hline 7 & Turnover & 80 & 64 & 21 & 64 & 121 & 350 & 1132 & 3.23 & 0.65 & $5^{\mathrm{TH}}$ \\
\hline & Health and Safety & & & & & & & & & & \\
\hline 1 & $\begin{array}{c}\text { Site safety certification } \\
\text { from required professional } \\
\text { body }\end{array}$ & 32 & 67 & 60 & 64 & 127 & 350 & 1237 & 3.53 & 0.71 & $1^{\mathrm{ST}}$ \\
\hline 2 & Management safety policy & 22 & 43 & 129 & 85 & 71 & 350 & 1190 & 3.40 & 0.68 & $2^{\mathrm{ND}}$ \\
\hline 3 & $\begin{array}{l}\text { Accident frequency } \\
\text { reporting and reward }\end{array}$ & 80 & 78 & 13 & 52 & 127 & 350 & 1118 & 3.19 & 0.64 & $5^{\mathrm{TH}}$ \\
\hline 4 & $\begin{array}{c}\text { Appointment of safety } \\
\text { officer }\end{array}$ & 80 & 40 & 80 & 100 & 50 & 350 & 1050 & 3.00 & 0.60 & $6^{\mathrm{TH}}$ \\
\hline 5 & $\begin{array}{l}\text { Safety training and } \\
\text { awareness meeting }\end{array}$ & 87 & 43 & 44 & 56 & 120 & 350 & 1129 & 3.23 & 0.65 & $4^{\mathrm{TH}}$ \\
\hline 6 & $\begin{array}{l}\text { Safety management plan } \\
\text { from a registered builder }\end{array}$ & 45 & 60 & 26 & 152 & 67 & 350 & 1186 & 3.39 & 0.67 & $3^{\mathrm{RD}}$ \\
\hline D & Reputations & & & & & & & & & & \\
\hline 1 & $\begin{array}{l}\text { Past Project completion } \\
\text { failure/success }\end{array}$ & 67 & 60 & 46 & 98 & 79 & 350 & 1112 & 3.18 & 0.64 & $6^{\mathrm{TH}}$ \\
\hline 2 & Length of time in business & 87 & 45 & 35 & 101 & 82 & 350 & 1096 & 3.13 & 0.63 & $7^{\mathrm{TH}}$ \\
\hline 3 & $\begin{array}{l}\text { Past client } \\
\text { relationship/certificates of } \\
\text { friendly project completion }\end{array}$ & - & 74 & 52 & 92 & 132 & 350 & 1332 & 3.81 & 0.76 & $2^{\mathrm{ND}}$ \\
\hline 4 & $\begin{array}{l}\text { Number of a similar } \\
\text { completed project }\end{array}$ & - & 134 & 23 & 77 & 116 & 350 & 1225 & 3.50 & 0.70 & $5^{\mathrm{TH}}$ \\
\hline 5 & $\begin{array}{l}\text { The reputation of the } \\
\text { subcontractors to be used } \\
\text { for the project. }\end{array}$ & - & 90 & 57 & 76 & 127 & 350 & 1290 & 3.69 & 0.74 & $3^{\mathrm{RD}}$ \\
\hline 6 & $\begin{array}{l}\text { Percent of previous works } \\
\text { completed on schedule }\end{array}$ & 53 & 117 & 42 & 31 & 107 & 350 & 1072 & 3.06 & 0.61 & $8^{\mathrm{TH}}$ \\
\hline 7 & Relationship with suppliers & - & 97 & 55 & 78 & 120 & 350 & 1271 & 3.63 & 0.72 & $4^{\mathrm{TH}}$ \\
\hline 8 & $\begin{array}{l}\text { Frequency of claims and } \\
\text { contractual dispute in the } \\
\text { previous contracts }\end{array}$ & - & 34 & 91 & 98 & 127 & 350 & 1368 & 3.91 & 0.78 & $1^{\text {ST }}$ \\
\hline
\end{tabular}




\begin{tabular}{|c|c|c|c|c|c|c|c|c|c|c|c|}
\hline \multirow[t]{2}{*}{ S/No } & \multirow{2}{*}{$\begin{array}{c}\text { Pre-Selection Contractor } \\
\text { Performance }\end{array}$} & \multicolumn{10}{|c|}{ Weighting/Response Frequency } \\
\hline & & 1 & 2 & 3 & 4 & 5 & $\left(\sum \mathbf{f}\right)$ & $\sum f \mathbf{f}$ & MEAN & RII & RANK \\
\hline $\mathbf{E}$ & Management Ability & & & & & & & & & & \\
\hline 1 & $\begin{array}{l}\text { Past management } \\
\text { performance }\end{array}$ & 100 & 12 & 13 & 105 & 120 & 350 & 1183 & 3.38 & 0.68 & $3^{\mathrm{RD}}$ \\
\hline 2 & $\begin{array}{c}\text { Qualification and } \\
\text { experience level of project } \\
\text { manager/building } \\
\text { construction manager }\end{array}$ & 17 & 68 & 22 & 138 & 105 & 350 & 1296 & 3.70 & 0.74 & $2^{\mathrm{ND}}$ \\
\hline 3 & $\begin{array}{c}\text { Qualification and } \\
\text { experience of management } \\
\text { staff }\end{array}$ & 96 & 98 & 29 & 100 & 27 & 350 & 914 & 2.61 & 0.52 & $5^{\mathrm{TH}}$ \\
\hline 4 & $\begin{array}{c}\text { Present workload and } \\
\text { capability to support the } \\
\text { new project }\end{array}$ & 53 & 105 & 05 & 132 & 55 & 350 & 1081 & 3.09 & 0.62 & $4^{\mathrm{TH}}$ \\
\hline 5 & $\begin{array}{l}\text { Number of own workers } \\
\text { available for the project }\end{array}$ & - & 41 & 72 & 144 & 93 & 350 & 1339 & 3.83 & 0.77 & $1^{\mathrm{ST}}$ \\
\hline $\mathbf{F}$ & Organization Culture & & & & & & & & & & \\
\hline 1 & $\begin{array}{l}\text { Contractors size and } \\
\text { complexity }\end{array}$ & - & 44 & 55 & 97 & 154 & 350 & 1411 & 4.03 & 0.81 & $2^{\mathrm{ND}}$ \\
\hline 2 & $\begin{array}{l}\text { Familiarity with the local } \\
\text { working culture }\end{array}$ & - & 46 & 100 & 83 & 121 & 350 & 1330 & 3.80 & 0.76 & $3^{\mathrm{RD}}$ \\
\hline 3 & $\begin{array}{c}\text { Contractor familiarity with } \\
\text { local suppliers }\end{array}$ & - & 30 & 06 & 97 & 169 & 350 & 1311 & 3.75 & 0.75 & $4^{\mathrm{TH}}$ \\
\hline 4 & $\begin{array}{c}\text { Familiarity with regulating } \\
\text { authority }\end{array}$ & - & 27 & 50 & 111 & 162 & 350 & 1459 & 4.17 & 0.83 & $1^{\mathrm{ST}}$ \\
\hline 5 & Experience in the region & 19 & 75 & 86 & 159 & 11 & 350 & 1118 & 3.19 & 0.64 & $5^{\mathrm{TH}}$ \\
\hline 6 & $\begin{array}{l}\text { Relationship with sub- } \\
\text { contractors }\end{array}$ & 50 & 100 & 30 & 144 & 26 & 350 & 1044 & 2.98 & 0.60 & $6^{\mathrm{TH}}$ \\
\hline 7 & $\begin{array}{l}\text { Contractor's familiarity } \\
\text { with weather conditions }\end{array}$ & 53 & 207 & - & 33 & 57 & 350 & 882 & 2.52 & 0.50 & 7TH \\
\hline
\end{tabular}

Table 4: Ranking ofRespondent's Opinions on the Importance of the Pre-Selection Contractors' Performance Source: Field Survey, (2019)

Where: 1-Strongly Disagree, 2-Disagree, 3-Undeceive, 4-Agree, 5- Strongly Agree

\section{Summary of Findings}

Based on the analysis carried out and the set research questions and hypotheses, the major findings of this study are:

The study revealed that some of the contracts were not awarded regarding any specific selection guideline but an executive award. Also, there is no framework or basis for evaluating contractor before the award of a public building contract neither is any evaluation basis during and after the execution of the contract.

Generally, the In-house performance evaluation guideline (52.5\%) is the major criteria used in the selection of contractors. However, the other alternative commonly used is the adoption of external agencies in the evaluation (23.8\%). On occasions where documents are demanded from contractors at the pre-selection stage, the most demanded document ranked based on the frequency of demand are: 'financial capacity/Bank support Document (RII= 0.61)'; 'Building Construction license' (RII=0.52); 'The Construction Organizational Structure' (RII=0.48) and 'The completed questionnaire issued by the client's body (RII=0.47).

The respondent's opinion/ranking of a range of varies n how important they are before the award of contract to contractors reveal that:

- For 'Technical/professional Capacity' (Engagement of technical/professional staff with relevant qualification and exposure' (RII=0.85) was the highest-ranked. This was closely followed by 'Plant and equipment: availability, conditions, and suitability of the equipment (RII=0.79); 'Quality management policy' (RII=0.77) and 'Specialized knowledge of the specified project' (RII=0.73); which were ranked second third and fourth respectively in the order of importance)

- For Financial Capability (Financial standing and stability' (RII=0.84) are the highest-ranked. While, Banking Support/ Guarantee' (RII=0.83) and 'Working capital' (RII=0.73) were ranked first, second and third in their order of importance).

- Health and Safety (Site safety certification from required professional body' (RII=0.71) as the most important health and safety pre-selectioncontractor performance criteria. Other highly ranked health criteria are Management safety policy' (RII=0.68); and 'Safety management plan from a registered builder' (RII=0.67), ranked second and third respectively).

- For the reputation (the respondents ranked contractor's capability to resolve issues on Frequency of claims and contractual dispute in the previous contracts $(\mathrm{RII}=0.78)$ as the most important criteria on the contractor pre- 
selection performance capability. Other top-ranked reputation criteria are Past client relationship/certificates of friendly project completion' (RII=0.76) and 'Reputation of the subcontractors to be used for the project' $(\mathrm{RII}=0.74)$ )

- For the management and organization culture, the top-ranked contractor performance criteria are: 'Number of own workers available for the project' $(\mathrm{RII}=0.77$ ) and 'Familiarity with regulating authority (RII=0.83) respectively.

\section{Conclusion}

With the increasing need to access a contractor's performance prior, during, and after the execution of and the reoccurring failure in the delivery of most public projects, there is a need to engage, monitor, and access any contractor to ensure effective project delivery. This reinforces the need to develop a framework for contractor assessment based on their performance. Protect. To this end, this study was conceived to study pre-qualification and selection guidelines for engaging contractors, the performance criteria/indicator, factors or measures to improve contractors' performance, and consequently the development of a framework for contractor performance evaluation alongside a formula for assessing contractor performance. Based on the summary of the major findings of the study as shown in section 4.10 and the research objectives in section 1.3, the following conclusion was drawn:

- Some of the contracts are not awarded regarding any specific selection guideline but basically on executive awards. However, in cases contractors are to be selected it is usually an in-house performance evaluation guideline and on such occasion, the most demanded pre-qualification documents demanded from the contractors arranged in the order of frequency of demand are: financial capacity/Bank support Document'; 'Building Construction license'; 'The Construction Organizational Structure' and 'The completed questionnaire issued by the client's body. The other document as identified by literature that ought to be demanded that are poorly ranked is because they are rarely demanded.

- While engaging contractor, the study concluded that the following document is paramount for engaging a contractor for effective project delivery: 'Engagement of technical/professional staff with relevant qualification and exposure'; 'Financial standing and stability; 'Banking Support/ Guarantee'; 'Site safety certification from required professional body'; 'Frequency of claims and contractual dispute in the previous contracts'; and 'Number of own workers available for the project'.

\section{Recommendation}

From the findings of the research, the following recommendations are made for the effective performance of contractors in the delivery of public building construction in Imo State:

- Since the study discovered that some of the contracts are not awarded using a stipulated guideline, the study recommends thorough examination of contractors at the pre-selection phases before engaging any contractor.

- In line with the extermination of contractors, contractors should be mandated to submit the necessary documentation such as identified by this study before engagement as this will provide a complete view of the strength and weaknesses of the contractor.

\section{References}

i. Armstrong, M. (2006). A Handbook of human resource management practice (10th edition). London and Philadelphia. Kogan Page Limited

ii. Beatham S., Anumba C., Thorpe T. and Hedges I. (2004). KPIs: a critical appraisal of their use in construction. Benchmarking: An International Journal, 11 (1), 93-117.

iii. Chartered Institute of Management Accountants (2010). New public sector performance; Making fiscal consolidation smarter. (Unpublished discussion paper)

iv. Chartered Institute of Management Accountants (2010). New public sector performance; Making fiscal consolidation smarter. (Unpublished discussion paper)

v. Dooren, W. \&Thijs, N. (2010). Paradoxes of Improving Performance Management (system) in public administration. Retrieved from HTTP;//www.Weipa. EU

vi. Dooren, W. (2006). Performance measurement in the Flemish public sector; a supply and demand approach. (Unpublished Ph.D. thesis) Catholic University, Leuven

vii. Gakure, R., Eliud, T. \&Karanja (n.d). Analysis of the factors that influence the implementation of performance contracting in state corporations; A case of Kenya Civil Aviation Authority. (Not published, master's thesis) Jomo Kenyatta University.

viii. Gatere A., Keraro V. \&Gakure R. (2013). The impact of performance contracts on service delivery at Teachers Service Commission in Kenya. Prime journals of business administration and management. ISSN; 2251-1261

ix. KobiaM.,\& Mohammed N. (2006). Kenyan experience with performance contracting. Africa Association for Public Administration and Management, Round table Conference, Arusha, Tanzania, December 2006

x. Lin J.,\& Lee P. (2011). Performance management in public organizations; A complexity perspective. International public management review; Vol. 12 ISS.2 page 81

xi. Mbachu, J. (2012). Knowledge and Skills Required for Contractors High Productivity and Performance in Construction Project Delivery: An Exploratory Study of the Upskilling Needs of the New Zealand Contractors. Proceedings of WEBER Conference 2012, Abuja, Nigeria, 859-869. 
xii. Mbachu, J. and Nkado, R.N. (2007) Factors Constraining Successful Building Project Implementation in South Africa, Construction Management and Economics, 25 (1), 39-54.

xiii. Mbamali I. (2009), Building practice in Nigeria: An overview of challenges of some emerging global trends. Paper presented at the National Conference of Department of Building Technology, Auchi Polytechnic with the theme challenges in building and environmental issues, 27th-29th May.

xiv. Mbamali, I and Okotie, A.J. (2012) American International Journal of Contemporary Research vol.2 N04: April 2012, 143-150.

xv. Mbamali, I., Aiyetan,O.A., and Kehinde,J.O. (2004). Building Design for Buildability: An Investigation of the Current Practice in Nigeria. Journal of Building and Environment, 40, 1267-1274

xvi. Obiegbu M.E. (2005). Due Process and Procurement methods in Construction Industry. Pp 23-47, proceedings of the 35th Annual General Conference of Nigerian Institute of Building held on Binez Hotels Ltd. Aba, 10th -14th August.

xvii. Obiegbu, M.E. (1992). Duties and Responsibilities of Site Agent in Contract Execution in BayoOlategu (ed) pp 2434, Proceeding of National Seminar on Effective Contract Management Organized by Nigerian Institute of Building in Lagos, 22-23 August.

xviii. Obiegbu, M.E. (1992). Duties and Responsibilities of Site Agent in Contract Execution in BayoOlategu (ed) pp 2434, Proceeding of National Seminar on Effective Contract Management Organized by Nigerian Institute of Building in Lagos, 22-23 August.

xix. Salaheldin, S. I. (2009). Critical success factors for TQM implementation and their impact on the performance of SMEs. International Journal of Productivity and Performance Management, 58 (3), 215-237.

xx. Shaban A.S.S (2008) factors affecting the performance of construction projects in the Gaza ship. M.sc thesis submitted to the Department of Construction Management, Faculty of the Engineering Islamic University of GazaPalestine.

xxi. Takim, R and Akintoye A, (2002), performance indicators for successful construction project performance in Greenwood (Ed). 18th Annual ARCOM conference, 2-4 September 2002. University of Northernmbia Association of Research in Construction Management, vol 2.545-55.

xxii. Ugwu, O. O., \&Haupt, T. C. (2007). Key performance indicators and assessment methods for infrastructure sustainability—a South African construction industry perspective. Building and Environment, 42(2), 665-680.

xxiii. Usman D.N. and Alaezi J. (2016). The Role of Construction small and medium enterprises (SMEs) in economic development. Proceedings of the 46th Annual Builders Conference General Meeting 8th-12th August 2016, Benin City, Nigeria, 47-54.

xxiv. Usman D.N. and Alaezi J. (2016). The Role of Construction small and medium enterprises (SMEs) in economic development. Proceedings of the 46th Annual Builders Conference General Meeting 8th-12th August 2016, Benin City, Nigeria, 47-54.

xxv. Willis, J. (1996). A flexible framework for task-based learning. Challenge and change in language teaching, 52-62. 